\title{
Phosphate Solubilizing and Antifungal Activity of Root Endophyte Isolated from Shorea leprosula Miq. and Shoreal selanica (DC) Blume
}

\author{
Safinah Surya Hakim ${ }^{1 *}$, Sri Wilarso Budi², Maman Turjaman ${ }^{3}$ \\ ${ }^{1}$ Banjarbaru Forestry Research Institute, Jl. Ahmad Yani Km 28,7 Banjarbaru, South Kalimantan, Indonesia 70701 \\ ${ }^{2}$ Department of Silviculture, Faculty of Forestry, Bogor Agricultural University, Academic Ring Road, \\ Campus IPB Darmaga, Bogor, Indonesia 16680 \\ ${ }^{3}$ Research, Development and Innovation Agency, Ministry of Environment and Forestry, \\ Jl. Gunung Batu No. 5 Bogor, West Java, Indonesia 16610
}

Received August 19, 2015/Accepted November 13, 2015

\begin{abstract}
Fungal endophytes are fungi that lives within plant tissues without causing apparent disease. It is also suggested that these fungi have ability to enhance plant growth and plant resistancy against pest and disease. This research is a preliminary study about root fungal endophytes in dipterocarp since there are lack research concerning about this study focus. We examined root fungal endophyte isolated from seedling of Shorea leprosula and Shorea selanica taken from Dramaga Experimental Forest, Bogor. Furthermore, we also tried to find out the fungal potential ability to solubilize phosphate and suppres fungal pathogen by in vitro assay. Surface sterilization method was used to isolated fungal endophytes from root tissues. Trichoderma spirale, Velsalceae sp., Melanconiela ellisii, Chaetosphaeria callimorpha, and Trichoderma asperellum were isolated during this study. These fungi appear to have specific association between fungal species and host plant, but no evidence of fungal order-level specificiation in S. leprosula and S. selanica. In vitro test also suggested that root fungal endophyte Trichoderma spirale and Melanconiella elisii have potential ability to solubilize inorganic phosphate. In addition, this result also present that root fungal endophyte T. spirale and T. asperellum have the potential to inhibit pathogen fungi Fusarium sp.
\end{abstract}

Keywords: root endophyte, biofertilizer, bioinsectisicide, biocontrol, phosphate solubilizing fungi

*Correspondence author,email: safinah.hakim@gmail.com,ph.: +62-511-4707872

\section{Introduction}

Naturally, plants have interaction with soil organism (Das \& Varma 2009). Studies have shown that interaction between plants and microorganism positively affect plant growth, plant health, increasing plant biomass, alter plant adaptation through stress condition, and etc (Bonkowski et al. 2000; Hrynkiewicz \& Baum 2011). In forest tree, the interaction between trees and mycorrhiza is well studied. Currently, many forest plantations use mycorrhiza as biofertilizer in their plantation area. But unlike mycorrhiza, study about the interaction in forest trees and fungal endophyte in tropical region are less known.

Fungal endophyte are fungi that live within plant tissues without causing apparent disease and also suggested that fungal endophyte has functional effect on plant, producing various secondary metabolite, enhance plant resistance against pest and disease (Bayman 2007). Fungal endophyte are very ubiquitous in natural habitat (Schulz \& Boyle 2005). Association between trees and fungal endophyte formed many benefits that still need to be explore further. Some research reveal fungal endophytes advantages such as: increase uptake of $\mathrm{N}$ from soil and plant biomass (Jumponnen et al. 2001), enhance plant resistance against plant pathogen (Miller et al. 2002), producing secondary metabolite which has potential ability as a new bioresources for pharmaceutical and agricultural needs (Surnayaran et al. 2002). In addition, microorganism have ability to dissolve insoluble form of phosphate into plant available form (Pradan \& Suklana 2005). Therefore, microorganism could be potential bio-fertilizer due their ability to supply available phosphor for plant which are very limited in soil. Dipteorcarp tree is important trees in tropical forest due its function in ecology and economy. Some spesies of dipterocarp are now endangered due to overcutting, habitat degradation, and also illegal logging. Hence, many studied focused on establishment of dipterocarp tree including the interaction of dipterocarp tree with microorganisms. Based on many studies, dipterocarp trees are very well-known for their strong relationship with ectomycorrhiza (Lee 1998). Other research results also reveal that dipterocarp trees also have interaction with plant growth promoting bacteria (Sitepu et al. 2007). There is still inadequate information 
about interaction between dipterocarp trees and fungal endophytes. Study of endophyte in dipterocarp tree was done by Orachaipunlap et al. (2008) and Pragathi et al. (2013), but this study focuses on foliar endophyte.

Considering the lack study of endophyte in tropical forest especially in dipterocarp tree, this study was primarily aimed to observed the fungal biological biodiversity in tropical forest. In addition, this is also preliminary study for bioprospecting fungi in order to support the idea of environmental friendly and cost-effective approach forest eshtablishment.

\section{Methods}

Site location The study was carried out in September 2013 to July 2014 in Dramaga Experimental Forest of the Forest Research and Development Agency, Minsitry of Forestry (FORDA) in West Java Indonesia (S6 33'7" E106 45'11"). Dramaga Experimental Forest total area is about 60 ha and the elevation is $244 \mathrm{~m}$ asl. Annual rainfall is about $350 \mathrm{~mm}$ and the soil type is reddish latosol. Minimum temperature is at $20.1^{\circ} \mathrm{C}$ and $30.1^{\circ} \mathrm{C}$ at maximum.

Sample collection and isolation Root sample from seedlings of $S$. leprosula and $S$. selanica (height $30-50 \mathrm{~cm}$ ) were randomly collected from Dramaga Experimental Forest, Bogor, Indonesia and carefully excavated. Five seedling were collected for each species. The collected seedlings were placed in plastic bag and covered with watered tissues to keep the freshness; the seedlings were taken to the laboratory for the next process on the same day.

Isolation of root endophytic fungi Secondary root from seedling of $S$. leprosula and $S$. selanica were washed carefully with tap water to remove adhered soil in root surface and then cut into some pieces. Surface sterilization was done by modified immersion process refers to Achlich \&Sieber (1996) as follows $96 \%$ ethanol for $1 \mathrm{~min}, 20 \% \mathrm{H}_{2} \mathrm{O}_{2}$ for $3 \mathrm{~min}, 96 \%$ ethanol for $0.5 \mathrm{~min}$, and rinse with sterile water for $5 \mathrm{~min}$. Root pieces were cut into segment into $0.5-1$ $\mathrm{cm}$ in length, then transferred into Petri dish containing $1 \%$ malt extract agar (MEA) that are very common medium used for isolating endophyte fungi (Arnold et al. 2001). In total, 120 root segments of $S$. Leprosula and 126 root segments of $S$. Selanica collected from the field Petri dishes were incubated at room temperature until fungal growth appear (2-30 days). To ensure the quality of sterilization process, $100 \mu \mathrm{l}$ water of rinsed-water on petri dish containing $1 \%$ MEA. Fungi that growing out from the root tips were transferred into petri dish contain 1\% MEA to get the single culture. These activities were done in sterile condition under laminar air flow hood.

DNA Isolation, PCR and sequencing The edge of filamentous fungal colony were suspended in tube containing liquid 1\% MEA and incubated for 3-7 days. Harvested mycelia were transferred into microcentrifugetube and ground the mycelia with steriled mini-pestle. Fungal DNA Isolation was done by using Wizard Genomic Kit from Promega, USA. PCR was perfomed using $50 \mu \mathrm{L}$ solutions consist of $5 \mu \mathrm{L} 5 \mathrm{X}$ Go Taq Flexi buffer, 1 primer ITS1 (5'TCCGTAGGTGAACC TGCGG-3') $(10 \mu \mathrm{M}), 1$ primer ITS4 (5'-TCCTCCGCTT ATTGATATGC3') $(10 \mu \mathrm{M})$, and $5 \mu \mathrm{L}$
DNA template. PCR reaction was done by this following processes: initial denaturation for $5 \mathrm{~min}$ at $94{ }^{\circ} \mathrm{C}$, denaturation for $1 \mathrm{~min}$ at $94^{\circ} \mathrm{C}$, annealing for $1 \mathrm{~min}$ at $55^{\circ} \mathrm{C}$, elongation for $2 \mathrm{~min}$ at $72^{\circ} \mathrm{C}$, elongation for $7 \mathrm{~min}$ at $72^{\circ} \mathrm{C}$ after 24 cycle, and final extension for $4 \mathrm{~min}$ at $72^{\circ} \mathrm{C}$. DNA fragment visualized with 2\% Agarose-electroporesis Gel in TAE buffer for $32 \mathrm{~min}$ at $100 \mathrm{~V}$. Good Quality DNA from PCR demonstrated by DNA bands submitted for DNA Sequencing. Fungi were amplified using universal primer ITS 1 and ITS 4. The sequences were compared with available DNA sequences in GenBank database of NCBI using BLAST programme. Phylogenetic tree was performed with software Clustal X 1.83 and MEGA 5.2.2.

In vitro phosphate solubilizing ability test Fungal plug of each isolate was placed in the center of PVK media which containing following ingredient $\left(\mathrm{g} \mathrm{L}^{-1}\right)$ (Sharma et al. 2011): glucose, 10.0; yeast extract, 0.5; $\left(\mathrm{NH}_{4}\right)_{2} \mathrm{SO}_{4}, 0.5$; $\mathrm{MgSO}_{4} .7 \mathrm{H}_{2} \mathrm{O}, \quad 0.1 ; \mathrm{Ca}_{3}\left(\mathrm{PO}_{4}\right)_{2}, 5 ; \mathrm{NaCl}, 0.2 ; \mathrm{KCl}, 0.2$; $\mathrm{MnSO}_{4} \cdot \mathrm{H}_{2} \mathrm{O}, 0.002 ; \mathrm{FeSO} 4.7 \mathrm{H}_{2} \mathrm{O}, 0.002$; agar, 15. For each isolates, the experiment was performed in triplicates. Observation was done after 72 hours. Fungal ability in phosphate solubilizing was indicated by clear zone solubilization index (SI) were calculated by the ratio of total diameter (colony and clear zone) and colony diameter.

Antagonistic test of fungal endophyte against pathogen Fusarium sp. Antagonistic test of fungal endophyte was carried out with dual inoculation method. Fungal root rot pathogen of Anthocepalus cadamba, Fusarium sp. was obtain from plant pathogen laboratory of Faculty of Forestry, Bogor Agricultural University. Petri dish $(\mathrm{d}=9 \mathrm{~cm})$ contain PDA were used for this antagonistic test with $5 \times 5 \mathrm{~mm}$ fungal plug. The fungal plug was placed in $3 \mathrm{~cm}$ distance from the edge, opposed on the same diagonal line. Three replications were used for this antagonistic test. Single culture test of each isolates were uses as control. Percentage of growth inhibition were calculated using the formula: $100 \times(\mathrm{C}-$ $\mathrm{T} / \mathrm{C})$, where $\mathrm{C}=$ control and $\mathrm{T}=$ treatment. Monitoring were done in $3^{\text {rd }}$ and $7^{\text {th }}$ days after inoculation.

\section{Results and Discussion}

Isolation of root endophytic fungi surface sterilization is common method to isolate endophytic fungi from root (Schulz et al. 1993; Bayman 2007; Silvani et al. 2008). In this research, we refer to sterilization method used by Achlich and Sieber (1996) and we modified this method to obtain maximum result (Hakim et al. 2014). The presence of root endophytic fungi in $S$. leprosula and $S$. selanica was indicated by mycelia growth from the tip of sterilized root segment. A total 16 isolates were isolated from $S$. leprosula (7 isolates) and $S$. selanica (9 isolates). Colonization percentage is relatively low (Table 1$)$.

Percentage of root endophytes colonization are varied depending on tree species. Achlich and Sieber (1996) reported the colonization percentage of dark septate endophytes in Fagus sylvatica is $5-14 \%$ and in common Pinacea trees was 43-67\%. In addition, Achlich and Sieber (1996) also generalized that fungal isolated in root tree of temperate forest was between $70-100 \%$. Colonization percentage of endophytic fungi in this study is relatively low 
Table 1 Result of fungal endophytes Isolation from root of Shorea leprosula and Shorea selanica

\begin{tabular}{lcc}
\hline \multirow{2}{*}{ Parameter } & \multicolumn{2}{c}{ Host } \\
\cline { 2 - 3 } & Shorea leprosula & S. horea selanica \\
\hline Number of root segment & 120 & 126 \\
Number of colonized root & 7 & 9 \\
Colonization percentage & $5.8 \%$ & $7.1 \%$ \\
\hline
\end{tabular}

compare to other researcher which are $5.8 \%$ in $S$. leprosula and $7.1 \%$ in $S$. selanica. Thus, the theory is not applicable in this study. Low percentage of fungal colonization suggests that there are competition between endophyte fungi and ectomycorrhiza fungi that live in the root of Shorea sp. and assumed that both of fungi employed the same niche. The cooccurence of mychorrizal and endophyte in plant root were identified (Fuchs \& Haselwandter K 2004; Wagg et al. 2008; Reinenger Sieber 2012; Soteras et al. 2013; Toju et al. 2013). According to Reinenger and Sieber (2012), there are correlation between ectomychorriza dan root endophytes in conifer species. This study reveal colonization of ectomycorrhiza form a phisical and physiological barrier to Dark Septeate Endophytes Phialocepala fortinii. In addition, the greater colonization of mycorrhiza could reduce the colonization of endophytes in the roots. Soteras et al. (2013) reported that higher colonization percentage of dark septate endophyte in root Polyepis australis decreasing the colonization of arbuscular mycorrhiza fungi. Furthermore, this result relevant to the assumtion that the colonization of root and foliar endophytes also correlated with colonization of arbuscular mycorrhiza (Novas et al. 2009; Eschen et al. 2010). Therefore, we can generated that the colonization of root endophytes influenced plant-mycorrhiza.

Identification Observation of fungal growth in 1\% MEA, showed that there are 5 distinctly morphospecies of root fungal endophyte. Each morphospecies was observed with microscope (Figure 1) and subsequently samples were identified by molecular analysis.

ITS regions were amplified using universal primer ITS1 and ITS4 which are common primer to identify endophytic fungi (Hallman et al. 2006). Five distinct morphospesies was obtained in this study (Table 2 and Figure 1). As expected, all PCR product showed a single visible band about $450-550$ bp on agarose gel $2 \%$ (Figure 2 ). Sequencing result then compared with sequence available from the gene bank. The result performed with BLAST showed that 5 isolated endophytic fungi identified as Trichoderma spirale, Velsacea sp, Melanconiela elisii, Chaetosphaeria callimorpha, and Trichoderma asperellum. All identified fungi are belongs to Ascomycota fungi. This result support study result of that majority of endophytic fungi belong to fungi group Ascomycota (Petrini 1991; Kageyama et al. 2008). Host specifity also appear in this study. Fungi isolated from $S$. leprosula were different with fungi isolated from $S$. selanica. According to Schulz \& Boyle (2005), endophytic fungi in tropical area are specific to particular host. Fungal specificity in particular host was affected by secondary metabolic produced by host plant (Bayman 2007).

Phylogenetic analysis was conducted by comparing the sequences of isolated endophytic fungi with the 18 sequences available on gene bank. The phylogenetic tree result showed that five isolated fungi during this study belong to 3 groups of fungal order which are Diaporthales, Hypocreales, and Chaetosphariales (Figure 3).

Valsaceae sp and M. elisii which are isolated during this study belong to fungi order Diaphorthales. Diaphorthales fungi were reported as a saprobes, pathogen, and endophyte in woody plant (Rossman et al. 2007). Study result of Toju et al. (2013) and De Souza et al. (2013) succesfully isolated some Diaphorthales fungi from Quercus serrate and mangrove plants. According to Sieber (2007), plants which belong to Angiospermae are dominated by endophytic fungi that belong to order Diaporthales and Hypocreales. T. spirale and T. asperellum belongs to fungi order Hypocreales. Hypocreales fungi characterized by its green conidia and fungi in order Hypocreales divided into two genuses which are Hypocrea and Trichoderma (Chaverrri et al. 2003).

Trichoderma sp., commonly categorized as soil saprophytes, but some researches also describes Trichoderma species as a plant endophytes (Achlich \& Sieber 1996; Bailey et al. 2011; de Souza Sebastianez et al. 2013). In Brazilian mangrove forest, Trichoderma species known as the one of the most frequent species isolated during the research (8.72\%) (de Souza Sebastianez et al. 2013). In addition, Endophytic fungi isolated from Trichoderma hamatum enhances seedling growth and delays onset in Theobroma cacao (Bailey et al. 2011). Regarding to this condition, it is assumed that Trichoderma categorized as multifunctional fungi that has role as a endophytic fungus and saprobe as well. Term of multifunctional fungi, mentioned by Brundrett (2006). Brundrett (2006) reported that some fungus have multifunctional role. For example: Fusarium spp., known to have role as root endophyte, pathogen, orchid mycorrhizae, and saprophyte. Nowadays, there are many studies working on Trichoderma sp. including its application on forestry. According to Widyastuti (2007) Trichoderma sp. can be use for pathogen biocontrol in pine, acacia, and teak wood. Trichoderma sp. as a biocontrol also studied by SantosVilabos et al. (2013). In their study, Trichoderma asperellum has significant effect against pathogen in mango fruit.

Chaetosphaeria callimorpha is a fungal species that belongs to fungus order Chaetosphaeria and genus Chaetosphaeria. Fungi in thus genus characterized with black and septate hypha (Reblova \& Winka 2000). Another study of Chaetosphaeria also done by Wright et al. (2009), and the study result showed that Chaetosphaeria was identified as ectomycorrhiza in tropical forest.

In vitro phosphate solubilizing ability test In vitro assay by using Pikovskhaya Media (PVK) to screening phospate solulubilizing ability by microorganisms is a common methods used by many researchers (Nautiyal 1999). Based on observation on PVK Media, out of 5 isolates obtained during this study only 2 isolates showed ability to produce clear zone in PVK media which are T. spirale and M. elisii (Table 3) with solubilization index are 0.12 and 0.64 , respectively. 
Table 2 Identification of endophytes isolates

\begin{tabular}{cllcc}
\hline Isolat Code & \multicolumn{1}{c}{ Species Name } & Order & Identification (\%) & Accesion No. \\
\hline SLA & Trichoderma spirale & Hypocreales & 100 & KC581162.1 \\
SLB & Velsalceae sp. & Diaporthales & 89 & AB334109.1 \\
SSC & Melanconiela ellisii & Diap orthales & 89 & JQ926271.1 \\
SSD & Chaetosphaeria callimorpha & Chaetosphaeriales & 86 & AF178555.1 \\
SSE & Trichoderma asperlum & Hypocreales & 100 & KF815050.1 \\
\hline
\end{tabular}
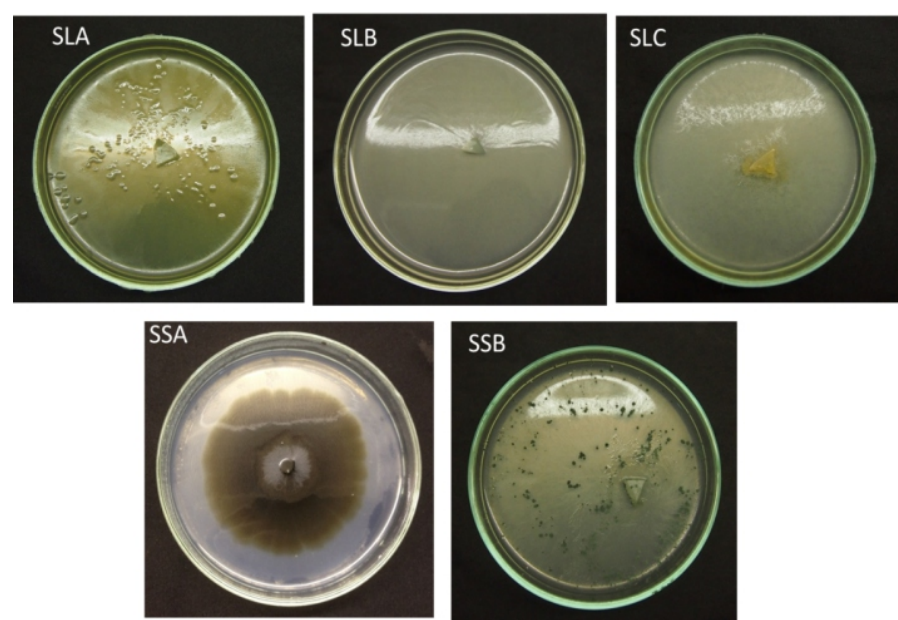

Figure 1 Fungal endophyte from root of Shorea leprosula and Shorea selanica.

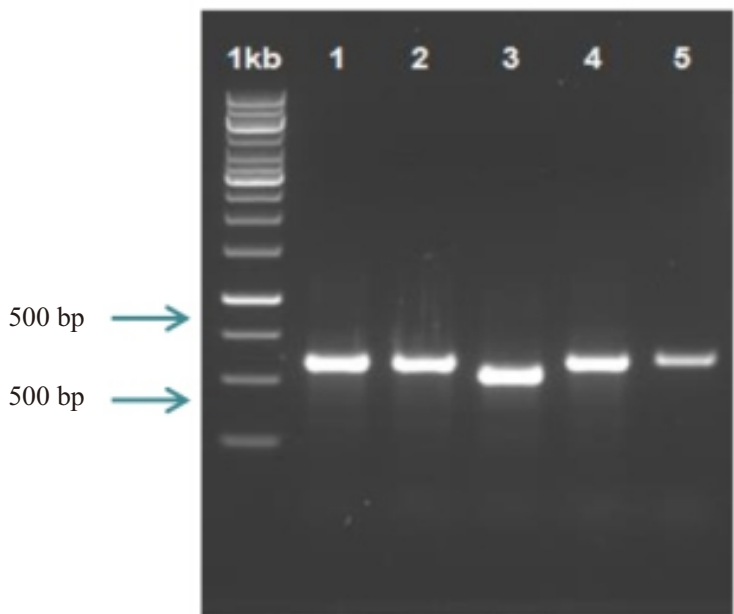

Figure 2 PCR amplification of sequence DNA with ITS1 and ITS 4 (Lane 1: Ladder; Lane 2,3,4,5,6 : SLA, SLB, SSC, SSD, and SSE).

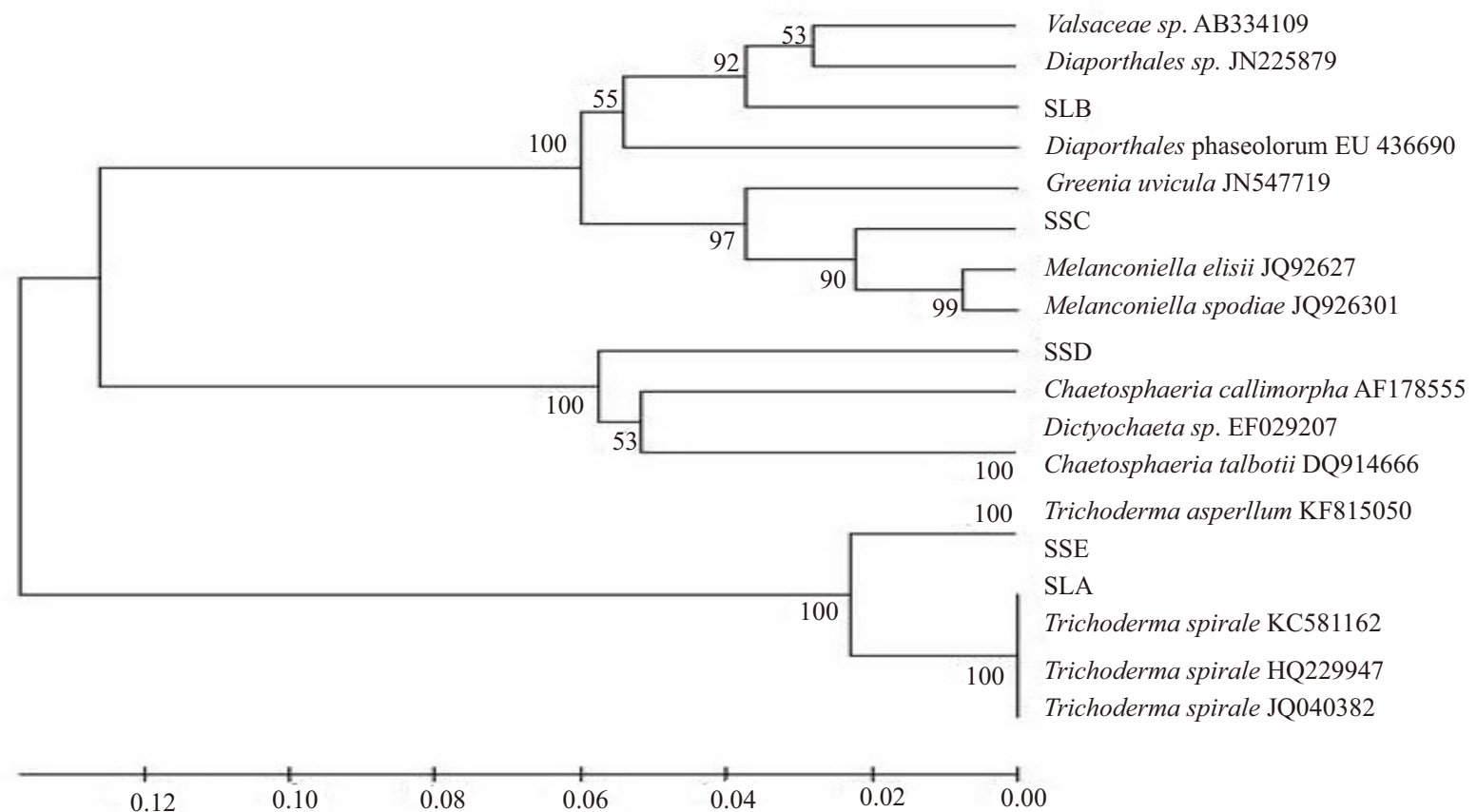

Figure 3 Phylogenetic tree of fungal root endophytes of Shorea leprosula and Shorea selanica. 
It is assumed that fungi with solubilize phosphate ability can produce clear zone has potential ability to support plant growth. This assumtion relevant with study result) that dark septate endophte isolated from Atriplex canescens, and Aspergillus ustus have ability to produce clear zone during in vitro test, can increase $\mathrm{P}$ content in inoculated plant compare with non-inoculated plant (Barrow \& Osuna 2002). In some research, Trichoderma $s p$. has been recognize as a phospate solubilizing fungi (Altomare et al. 1999; Kapri et al. 2010; Rudesh et al. 2015). According to Rudesh et al. 2015, Trichoderma sp. has ability to produce organic acid which could solubilize insoluble phosphate. In addition, glasshouse experiment also reveal that the Trichoderma sp. also increase plant biomass. Therefore, it is assumed that fungal endophytes $T$. spirale also have potential to enhance plant growth. Unlike the Trichoderma sp., there are lack report about the ability of Melanconiella elissii to solubilize phosphate. However, it is assumed that the fungal with producing clearzone ability in vitro have similar mechanism.
Antifungal activity of fungal endophyte Naturally, there are many biological active compounds which have antifungal activity against fungal pathogens. These active biological compounds could be isolated from living organ such as plant leaves, bark, stem (Darma et al. 2006), and from fungal endophytes. Trichoderma sp. are the most frequently studied fungi as biocontrol agents for disease control and also studied for its secondary metabolites production (Verma et al. 2007; Widyastuti 2007; Hoyos-Carvajal et al. 2009). Therefore, antagonistic test of fungal endophyte and pathogen Fusarium sp. focused only on Trichoderma sp. which are isolated in this research. There are two Trichoderma species isolated during this research which are T. spirale and T. asperellum. Antagonistic test was carried out by dual inoculation method.

Dual culture test showed that endophytic fungi Trichoderma sp has growth inhibition effect against pathogen Fusarium sp. (Table 4), ilustrated that Trichoderma sp in 3 day after inoculation, radial growth inhibitionover

Table 3 Mycelia growth and clear zone of fungal endophyte from root of Shorea leprosula and Shorea selanica on PVK media after 3 days

\begin{tabular}{|c|c|c|c|}
\hline $\begin{array}{l}\text { Incubation time } \\
\text { (days) }\end{array}$ & $\begin{array}{l}\text { Antagonistic test (Fusarium sp.) } \\
\text { species }\end{array}$ & Radial growth* & $\%$ Radial growth inhibition* \\
\hline \multirow[t]{2}{*}{3} & Trichoderma spirale & 2.33 & $8.63 \%$ \\
\hline & $\begin{array}{l}\text { Trichoderma asperellum } \\
\text { Control }\end{array}$ & 1.97 & $22.75 \%$ \\
\hline \multirow[t]{3}{*}{7} & Trichoderma spirale & 2.63 & $45.58 \%$ \\
\hline & Trichoderma asperellum & 3.8 & $21.37 \%$ \\
\hline & Control & 4.83 & \\
\hline
\end{tabular}

*Each value is the means of three replicates \pm standard error

Day-3
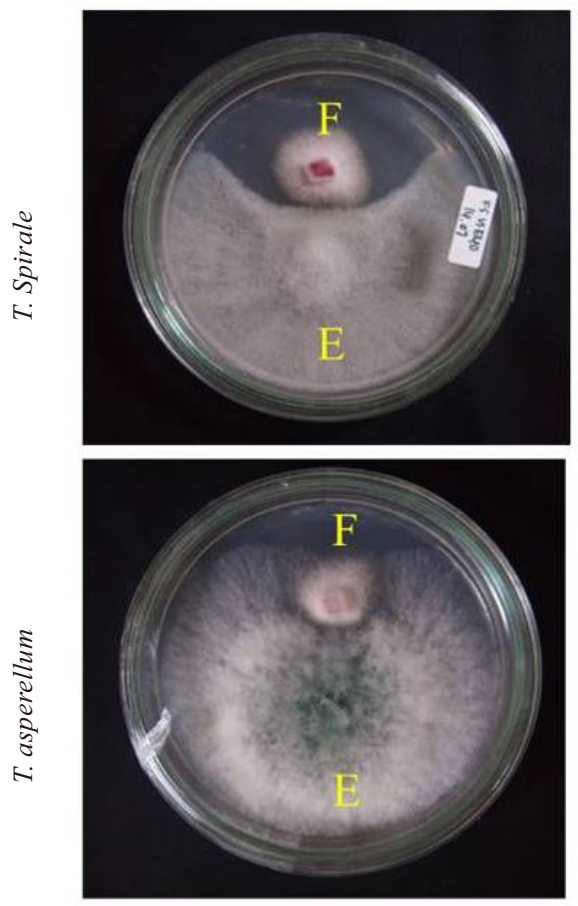

Day-7
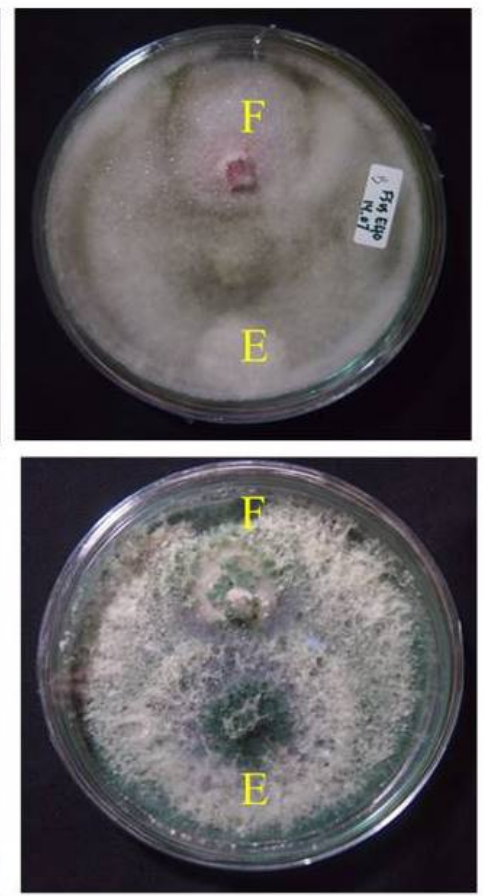

Figure 4 Antagonism test of endophyic fungi Trichoderma spirale and Trichoderma asperellum to pathogenic fungi Fusarium sp in $3^{\text {rd }}$ and $7^{\text {th }}$ days after inoculation ( $\mathrm{E}=$ endophyte fungi; $\mathrm{F}=$ pathogen). 
Table 4 Evaluation of root endophyte Trichoderma spirale and Trichoderma asperellum against pathogen Fusarium sp. in $3^{\text {rd }}$ and $7^{\text {th }}$ days after inoculation

\begin{tabular}{|c|c|c|c|}
\hline Species & $\begin{array}{c}\text { Mycelia growth* } \\
(\mathrm{cm})\end{array}$ & $\begin{array}{c}\text { Clear zone* } \\
(\mathrm{cm})\end{array}$ & Solubilization Index (SI) \\
\hline Trichoderma spirale & $8 \pm 0$ & $0.98 \pm 0.13$ & 0.12 \\
\hline Velsalceae sp. & $4.62 \pm 3$ & 0 & 0 \\
\hline Melanconiela ellisii & $7.93 \pm 0.13$ & $5.1 \pm 1.05$ & 0.64 \\
\hline Chaetosphaeria callimorpha & $0.65 \pm 0$ & 0 & 0 \\
\hline Trichoderma asperellum & $8 \pm 0$ & 0 & 0 \\
\hline
\end{tabular}

control are $8.63 \%$ (T. spirale) and $22.75 \%$ (T. asperellum). In addition, seventh days after inoculation $T$. spirale and $T$. asperellum inhibited pathogen growth by $45.58 \%$ and $21.37 \%$ over control, respectively. The ability of Trichoderma species supress growth of pathogen Fusarium sp has been widely demonstrated (Cotxarrera et al. 2002; Srivastava et al. 2010; Bhale et al. 2013).

According to Verma et al. (2007), there are 3 mechanism modes of Trichoderma $s p$. fungi to inhibit pathogen fungi which are mycoparasitsm, antibiosis, and competition. Antagonism mechanism of Trichoderma sp. fungi against pathogen are involving many complex processes. In mycoparasitsm mechanism, there are several step which are host recognition process, penetration and killing the pathogen fungi. In this mechanism, fungi Trichoderma sp. release cell wall degrading enzym (CDWE) (Vinale et al. 2008). Unlike the mycoparasitism process that resulting the dead of the antagonist, in antibiosis mechanism, Trichoderma sp. only supressing fungal growth by space competition which resulting growth inhibition of antagonist fungi (Verma et al. 2007). In the near future, the ability of endophyte fungi to surpress plant pathogen growth area should include in vivo studies.

\section{Conclusion}

Isolation and in vitro assay of root fungal endophytes from S. selanica and S. leprosula suggested that fungal endophyte has potential ability as a biofertilizer and biofungicide. Based on in vitro test, fungal endophytes capable to solubilize phosphate. Furthermore, the dual inoculation between fungal endophytes and pathogen Fusarium sp. play a potential role of fungal endophytes to control the growth of plant fungal pathogen. This result suggest that fungal endophytes have a many undiscovered potential roles to support plant growth.

\section{Acknowledgments}

Many thanks to Resti Ariantari S.Si for technical assitance during fungal isolation process and Sira Stephanandra for molecular analysis. This research was funded by Tanoto Foundation and Microbiology Laboratory of Forestry Research and Development.

\section{References}

Achlich K, Sieber TN. 1996. The profusion of dark septate endophytic fungi in non-ectomycorrhizal fine roots of forest trees and shrubs. New Phytology 132:259-270. http://dx.doi.org/10.1111/j.1469-8137.1996.tb01845.x.

Altomare C, Norvell WA, Bjorkman T, Harman GE. 1999. Solubilization of phospates and micronutrients by the plant-growth-promoting and biocontrol fungus Trichoderma harzianum Rifai 1295-22. Applied and Environmental Microbiology 65(7):2926-2933.

Arnold AE, Maynar Z, Gilbert GS. 2001. Fungal endophytes in dicotyledonous neotropical trees: patterns of abundance and diversity. Mycological Research 105(12):1502-1507. http://dx.doi.org/10.1017/ S0953756201004956.

Bailey BA, Bae H, Melnick R, Crozier J. 2011. The endophytic Trichoderma hamatum isolate DIS 219b enhances seedling growth and delays the onset of drought stress in Theobroma cacao. In : Pirttila AM, Frank AC, editors. Endophytes of Forest Trees. Dordecht : Springer Science+Bussiness Media. http://dx.doi.org/10.1007/ 978-94-007-1599-8 10.

Barber SA. 1984. Soil Nutrient Bioavailability: A mechanistic approach. USA: Wiley Interscience Publication.

Barrow JR, Osuna P. 2002. Phosphorus solubilization and uptake by dark septate fungi in fourwing saltbush, Atriplex canescens (Pursh) Nutt. Journal of Arid Environments 51:449-459. http://dx.doi.org/10.1006 /jare.2001.0925.

Bayman P. 2007. Fungal Endophytes. In: Kubicek CP and Druzhinina IS, editors. Environmental and Microbial Relationship $2^{\text {nd }}$ Edition. Berlin: Springer.

Bhale UN, Wagh PM, Rajkonda JN. 2013. Antagonistic confrontation of Trichoderma spp. Against fruit rot pathogens on Sapodilla (Manilkara zapota L.). Journal of Yeast and Fungal Research 4(1):5-11. http://dx.doi. org/10.5897/JYFR12.029

Bonkowski M, Cheng W, Griffiths BS, Alphei J, Scheu S. 2000. Microbial-fauna interactions in the rhizosphere and effect on plant growth. European Journal of Soil Biology 
36:135-147. http://dx.doi.org/10.1016/S11645563(00)01059-1.

Brundrett MC. 2006. Understanding the roles of multifunctional mycorrhizal and endophytic fungi. In: Schulz B, Boyle C, Sieber T, editors. Microbial Root Endophytes. Heidelberg: Springer-Verlag. http://dx.doi.org/10.1007/3-540-33526-9_16.

Chaverri P,Castlebury LA, Barrie EO. 2003. Hypocrea/Trichoderma: species with conidiophore elongations and green conidia. Mycologia 95(6):1100-1140. http://dx.doi.org/10.2307/3761915.

Cotxarrera L, Trillas-Gay MI, Steinberg C, Alabouvette C. 2001. Use of sewage sludge compost and Trichoderma asperellum to supress fusarium wilt tomato. Soil Biology and Biochemistry 34:467-476. http://dx.doi.org/10. 1016/S0038-0717(01)00205-X.

Das A, Varma A. 2009. Symbiosis: the art of living. In: A Varma, Kharkwal AC, editors. Symbiotic Fungi. Berlin: Springer. http://dx.doi.org/10.1007/978-3-540-958949_1.

Darma T, Azuma M, Mitani M, Itoh K, Tachibana S, Tamai Y. 2006. Antifungal activities of the extract from tropical and temperate woods. Jurnal Manajemen Hutan Tropika $8(2): 78-83$.

De Souza Sebastianes SL, Romao-Dumaresq AS, Lacava PT, Harakva R, Azevedo JL, de Melo I; Pizzirani-Kleiner AA. 2013. Species diversity of culturable endophytic fungi from Brazilian mangrove forests. Current Genetics 59:153-166. http://dx.doi.org/10.1007/s00294-0130396-8.

Eschen R, Hunt S, Mykura C, Gange AC, Sutton BC. 2010. The foliar endophyte fungal community composition in Cirsium arvense is affected by mycorrhizal colonization and soil nutrient content. Fungal Ecology 114:991-998. http://dx.doi.org/10.1016.j.funbio.2010.09.009.

Fuchs B, Haselwandter K. 2004. Red list plants : colonization by arbuscular mycorrhizal fungi and dark septate endophytes. Mycorrhiza 14:277-281. http://dx.doi.org /10.1007/s00572-004-0314-5.

Hakim SS, Budi SW, Turjaman M. 2014. Surface sterilization to isolate fungal root endophytes of meranti tembaga (Shorea leprosula Miq.) in Dramaga Experimental Forest. Jurnal Silvikultur Tropika 5(1):49-53.

Hoyos-Carvajal L, Orduz S, Bisset J. 2009. Genetic and metabolic biodiversity of Trichoderma from Colombia and adjacent neotropic regions. Fungal Genetic and Biology 46:615-631. http://dx.doi.org/10.1016/j.fgb. 2009.04.006

Hallmann J, Berg G, Schulz B. 2006. Isolation Procedure for Endophytic Microorganism. In: Schulz B, Boyle C, Sieber T, editors. Microbial Root Endophytes. Berlin:
Springer-Verlag Berlin Heidelberg. http://dx.doi.org/ 10.1007/3-540-33526-9 17.

Hrynkiewicz K, Baum C. 2011. The potential of rhizosphere microorganisms to promote the plant growth in disturbed soils. In: Malik A, Grohmann E, editors. Environmental Protection Strategies for Sustainable Development, Strategies for Sustainability. Berlin: Springer-Verlag Berlin Heidelberg.

Jumpponen, A. 2001. Dark septate endophytes: are they mycorrhizal. Mycorrhiza 11:207-211. http://dx.doi. org/10.1007/s005720100112.

Kageyama SA, Mandyam KG, Jumpponen A. 2008. Diversity, function and potentia application of the rootassociated endophytes. In: Varma A, editor. Mycorrhiza. Berlin: Springer-Verlag. http://dx.doi.org/10.1007/9783-540-78826-3 2.

Kapri A,Tewari L. 2010. Phosphate solubilization potential and phosphatase activity of rhizospheric Trichoderma spp. Brazilian Journal of Microbiology 41(3):787-795. http://dx.doi.org/10.1590/S1517-83822010005000001.

Lee SS. 1998. Root symbiosis and nutrition. Appanah S and Turnbull JM, editors. A Review of Dipterocarps: Taxonomy, ecology and Silviculture. Bogor : CIFOR.

Miller JD, Mackenzie S, Foto M, Adams GW, Findlay JA. 2002. Needles of white spurce Inoculated with rugulosinproducing endophytes contain regulosin reducing spurce budworm growth rate. Mycologia Research 106(4):471-479. http://dx.doi.org/10.1016/j.funeco. 2009.01.002.

Nautiyal CS. 1999. An efficient microbiological growth medium for screening phosphate solubilizing microorganisms. FEMS Microbiology letter 170:265-270. http://dx.doi.org/10.1111/j.1574-6968.19 99.tb13383.x.

Novas MV, Iannone LJ, Godeas AM, Cabral D. 2009. Positive association between mycorrhiza and foliar endophyte in Poa bonariensis, a native grass. Mycological progress 8:75-81. http://dx.doi.org/10. 1007/s11557-008-0579-8.

Orachaipunlap K, Roengsumran S, Sinahot P. 2009. Diversity of endophytic fungi isolated from plant leaves of decidious dipterocarp forest in Tak Province. Kasetsart Journal (Natural Science) 4:182-188.

Petrini O. 1991. Fungal endophytes of tree leaves. In: Andrews J, Hirano S, editors. Microbial Ecology of Leaves. New York : Springer Verlag. http://dx.doi.org/10. 1007/978-1-4612-3168-4_9.

Pradan N, Sukla LB. 2005. Solubilization of inorganic phosphates by fungi isolated from agriculture soil. African Journal of Biotechnology 5(10):850-854. 
Pragathi D, Vijaya T, Mouli KC, Anitha D. 2013. Diversity of fungal endophytes and their bioactive metabolites from endemic plants of Tirumala hills-Seshachalam biosphere reserve. African Journal of Biotechnology 12(27):4317-4323. http://dx.doi.org/10.5897/AJB2013. 12154.

Srivastava R, Khalid A, Singh US, Sharma AK. 2010. Evaluation of arbuscular mycorrhizal fungus, fluorescent Pseudomonas and Trichoderma harzianum formulation against Fusarium oxysporum f. sp. Lycopersici for the management of tomato wilt. Biological control 53:24-31. http://dx.doi.org/10.1016/j.biocontrol. 2009.11.012.

Reinenger V, Sieber TN. 2012. Mycorrhiza reduces adverse effects of dark septate endophytes (DSE) on growth of conifers. PLoS ONE 7(8):e42865. http://dx.doi.org/ 10.1371/journal.pone.0042865.

Reblova M and Winka K. 2000. Phylogeny of Chaetosphaeria and its anamorphs based on morphological and molecylar data. Mycologia 92(5):939-954.http://dx.doi.org/10.2307/3761589.

Rossman AY, Farr DF, Castlebury LA. 2007. A review of the phylogeny and biology of Diaporthales. Mycoscience (48):135-144. http://dx.doi.org/10.1007/S10267-007$0347-7$.

Rudesh DL, Shivaprakash MK, Prasad RD. 2005. Tricalcium phosphate solubilizing abilities of Trichoderma spp. in relation to $\mathrm{P}$ uptake and growth and yield parameters of chickpea (Cicer arietinum L.). Canadan Journal of Microbiology 51:217-222. http://dx.doi.org/10.1139/ W04-127.

Santos-Villalobos S, Guzman-Ortiz DA, Gomez-Lim MA, Délano-Friera JP, de-Foltera S, Sánchez-Garcíab S, PeñaCabriales JJ. 2013. Potential use of Trichoderma asperllum $\mathrm{T} 8$ as a biological control agent against antracnose in mango (Mangifera indica). Biological Control 64:37-44. http://dx.doi.org/10.1016/j.bio control.2012.10.006.

Schulz B, Boyle C. 2006. What are Endophytes? In: Schulz B, Boyle C, Sieber TN, editors. Microbial root endophytes. Berlin: Springer. http://dx.doi.org/10.1007/ 3-540-33526-9 1.

Schulz B, Boyle C. 2005. Review: The endophytic continuum. Mycological Research 109(6):661-686. http://dx.doi.org/10.1017/S095375620500273X.

Schulz B. 2006. Mutualistic Interaction with Fungal Root Endophytes. In: Schulz B, Boyle C, Sieber TN, editors. Microbial root endophytes. Verlag Berlin Heidelberg: Springer. http://dx.doi.org/10.1007/3-540-33526-9_15.

Schulz B, Wanke U, Draeger S, Aust HJ. 1993. Endophytes from herbaceous plant and shrubs: Effectiveness of surface sterilization methods. Mycological Research
97:1447-1450. http://dx.doi.org/10.1016/S09537562(09)80215-3.

Sharma S, Kumar V, Tripathi RB. 2011. Isolation of phosphate solubilizing microorganism (PSMs) from soil. Microbiology and Biotechnology Reserach 1(2):90-95.

Sieber TN. 2007. Endophytic fungi in forest trees: Are they mutualist? Fungal Biology Review 21:75-89. http://dx.doi.org/10.1016/j.fbr.2007.05.004.

Silvani VA, Fracchia S, Fernandez L, Pergola M, Godeas A. 2008. A simple method to obtain microorganism from fiels-collected roots. Soil Ecology and Biochemistry 40:1259-1263. http://dx.doi.org/10.1016/j.soilbio. 2007.11.022.

Sitepu IR, Aryanto, Ogita N, Osaki M, Santoso E, Tahara S, Hashikado Y. 2007. Screening of Rhizobacteria from dipterocarp seedling and sapling for the promotion of early growth of Shorea selanica seedling. Tropics 16(3):245-252. http://dx.doi.org/10.3759/tropics. 16.245

Soteras F, Renison D, Becerra AG. 2013. Growth response, phosphorus content and root colonization of Polylepis australis Bitt. Seedlings inoculated with different soil types. New Forests 44:577-589. http://dx.doi.org/10. 1007/s11056-013-9364-X.

Sun X, Ding Q, Hyde KD, Guo LD. 2012. Community structure and preference of endophytic fungi of three woody plants in a mixed forest. Fungal Ecology 5:624-632. http://dx.doi.org/10.1016/j.funeco.2012. 04.001 .

Suryanarayan TS, Thirunavukkarasu N, Govindarajulu MB, Sasse F, Jansen R, Murali TS. 2009. Fungal endophytes and bioprospecting. Fungal Biology Reviews 23:9-19. http://dx.doi.org/10.1016/j.fbr.2009.07.001.

Toju H, Yamamoto S, Sato H, Tanabe AS. 2013. Sharing of diverse mycorrhizal and root-endophytic fungi among plant species in an oak-dominated cool-temperate forest. PLoS ONE 8(10):e78248. http://dx.doi.org/10. 1371/journal.pone.0078248.

Verma M, Brar SK, Tyagi RD, Surampalli RY, Valero JR. 2007. Antagonistic fungi, Trichoderma spp.: panolply of biological control. Biochemical Engineering Journal 37:1-20. http://dx.doi.org/10.1016/j.bej.2007.05.012.

Vinale F, Sivasithamparam K, Ghisalberti EL, Marra R, Woo SL, Lorito M. 2008. Trichoderma-plant-pathogen interactions. Soil Biology and Biochemistry 40:1-10. http://dx.doi.org/10.1016/j.soilbio.2007.07.002.

Wagg C, Pautler M, Massicotte HB, Peterson L. 2008. The co-occurance of ectomycorrhizal, arbuscular mycorrhizal, and dark septate fungi in seedling of four members of the Pinaceae. Mycorrhiza 18:103-110. http://dx.doi.org/10.1007/s00572-007-0157-y. 
Widyastuti SM. 2007. Peran Trichoderma spp. dalam Revitalisasi Kehutanan di Indonesia. Yogyakarta: Gajah Mada University Press.

Wright SH, Berch SM, Berbee ML. 2009. The effect of fertilization on the below-ground diversity and community composition of ectomycorrhizal fungi associated with western hemlock (Tsuga heterophylla). Mycorrhiza 19(4): 267-276. http://dx.doi.org/10.1007/ s00572-008-0218-x. 